This may have become a perennial problem. Two weeks ago, Michael L. Telson, an analyst with the House Budget Committee, warned the assembled administrators that the fight over the budget resolution was prophetic of what will happen in coming years.

He was speaking at an annual discussion of the federal research and development budget sponsored by the American Association for the Advancement of Science and based on a report* it issues each year. Telson said that so long as the Administration sticks to high defence spending and no major new tax revenue and does not lower the entitlements part of the budget (payments to individuals), the discretionary part of the civilian budget will become the scene of intense political competition. "Don't be surprised if you have trouble in the appropriations process that you never had before', Telson warned the group. "And don't take it personally.",

Telson presented a chart from the President's budget request in which civilian research and development is included in the "all other" column. It shows how much less money there will be overall in the fiscal year 1983 than even in fiscal 1982.

David A. Shirley, director of the Lawrence Berkeley Laboratory (LBL) in California, gave the meeting an idea of what the recent budget shifts mean at the working level. LBL has no major weapons programmes or nuclear programmes and so has been particularly vulnerable to shifts in the civilian budget. When the President released the budget for the fiscal year 1982 in March 1981, the laboratory realized it

*W.H. Shapley, A.H. Teich \& J. Weinberg: Research and Development, AAAS Report VII. (American Association for the Advancement of Science, Washington, DC). would have to cut personnel by 10 per cent on 1 October. On 24 September, however, the Reagan Administration issued a revised budget for fiscal year 1982 which required a further cut of 300 employees, bringing the combined cut to 19 per cent. Seventy per cent of these cuts were made in basic research, Shirley said.

Now, Shirley said, there is a third cut coming for fiscal year 1983 in October, but he does not know its size because Congress and the Administration have not agreed on a budget. Legally, however, as director of the laboratory, he must give employees 90 days' notice of termination. He can make a guess now (something even soothsayers in Washington are not doing) or he can have the "full"' complement of employees working on 1 October, and then make larger cuts later.

Meanwhile, Dr George A. Keyworth, the President's science adviser, complained of the hue and cry scientists had raised about changes that had been proposed - which he described as a quest for priorities - in the year since he took office. On the whole, however, Keyworth said the scientists, meeting with him privately in small groups of " 20 or 30 a day", had been constructive, and anxious to help him set priorities. $\mathrm{He}$ boasted that the President's budget had done rather well by science - a conclusion the AAAS report supported - and took recent increases of 16 per cent in research and development spending by industry as evidence that US science is on the road to recovery (although others have attributed much of it to changed accounting due to new tax concessions). Having delivered his talk, and answered questions, he was out of the door before the moderator of the meeting had finished thanking him.

Deborah Shapley

\section{Universities outflanked by business lobby}

\section{Washington}

Congress gave final approval last week to a plan that will set aside 1.25 per cent of federal research funds for small businesses. The legislation, almost certain to be signed into law by President Reagan, was strongly opposed by universities, fearing reduced spending on basic research.

The universities, however, were no match for small business, which has a powerful position in Washington. The House of Representatives passed the measure by an overwhelming vote of $353-57$ and it was quickly approved by Senate (which last December had passed its own, similar version, by a $90-0$ vote).

Any federal agency having a research budget of more than $\$ 100$ million will be affected by the new measure. This includes the National Aeronauties and Space Administration, the National Institutes of Health, the Environmental Protection Agency, the Veterans' Administration, the Nuclear Regulatory Commission and the departments of defence, energy, agriculture, transportation, interior and commerce. After a three-year phase-in, the sums set aside will reach 1.25 per cent of each of these agencies' extramural research budgets (one-and-a-quarter per cent of the 1982 budgets would total $\$ 377$ million).

The chief concern of the universities is that although the percentage cut appears small, its effect on basic research funds will be greatly magnified. A spokesman for the Association of American Universities called it "very unfortunate". A large proportion of spending on current research goes into fixed costs and previous commitments to multi-year projects, he said. What is left is the more vulnerable support for new, basic research projects.

A deeper worry is that since small businesses - defined as firms with fewer than 500 employees - will still be able to compete for funds under the regular proposals that are unsuccessful in the general competition for funds. The bill's backers claim that peer-review of set-aside fund proposals will eliminate that problem. Stephen Budiansky programmes, the fund set aside will go to
Fancy technique

\section{St Louis}

From an industrial giant in the heart of California's "Silicon Valley" that specializes in conquering space in a minimum of time comes the latest in rapid communication - the homing pigeon.

At Lockheed Missiles and Space Company, a division of Lockheed Corporation, draughtsmen have gone beyond pencils and $\mathrm{T}$-squares to perform their intricate design work on a computer's video screen.

A courier had to spend $1 \frac{1 / 2}{2}$ hours travelling over congested highways and winding mountain roads to carry printouts from the Sunnyvale computer, 20 miles away, back to the designers, and designs done one day did not arrive until mid-afternoon on the following day.

That's where the homing pigeon stepped, or flew, in. The idea arose when someone heard about a hospital in England using the birds to transport blood samples. The company directed a
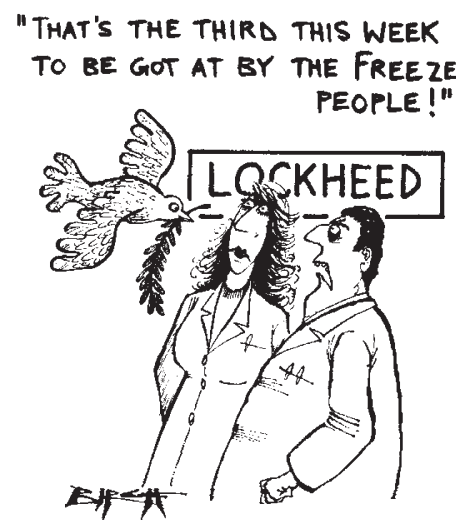

research chemist, Werner Deeg, to investigate. Deeg built a pigeon loft, and started with eight pigeons donated by local pigeon fanciers. He now thinks of pigeons as his hobby, and tends them in his lunch hour.

The pigeon courier service has been running since mid-December. A pigeon gets a lift down the mountain to Sunnyvale every afternoon with the regular courier. At the end of a day, a microfilm copy is made of the print-outs and the following morning the pigeon heads for home with the microfilm strapped to its leg. It's just a 20 minute flight as the pigeon flies.

The weather is the only problem said Deeg. "But, even so, we've been able to fly 85 per cent of the time." Why doesn't Lockheed have electronically-operated printers to transmit the data? It does but at $\$ 10$ a print, that system is used only as a back-up. The pigeon can carry a day's work, 30 or 40 blueprints, at a cost of about $\$ 1.50$.

“They live 12-15 years unless they're eaten by a hawk or fly into electric wire", Deeg said. He's proud of their record so far: "We've yet to lose a pigeon or a microfilm."

Karen Freeman 